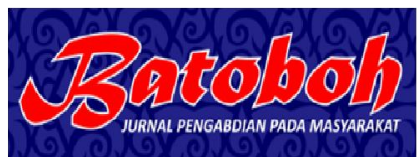

\title{
ВАТОВОН
}

Jurnal Pengabdian Pada Masyarakat

Available online at:https://journal.isi-padangpanjang.ac.id/index.php/Batoboh

\section{PELATIHAN FILM PENDEK UNTUK SISWA SMA}

\author{
FX. Yatno Karyadi \\ Prodi Televisi dan Film \\ Fakultas Seni Rupa dan Disain \\ Institut Seni Indonesia Padang Panjang \\ lagipanen@gmail.com
}

hal $\mid 1$

\begin{abstract}
ABSTRAK
Film pendek untuk siswa SMA adalah bentuk program pelatihan pembuatan karya seni film, dengan peserta siswa sekolah menengah atas. Film pendek adalah media audio-visual yang berdurasi kurang dari tiga puluh menit yang digunakan untuk mengekspresikan sebuah gagasan melalui media sinema. Pelatihan bertujuan untuk meningkatkan rangsangan bagi siswa dalam memperkaya pengetahuan tentang jenis seni media rekam yang kini dikenal dengan istilah digital cinema. Pelatihan menggunakan metode workshop dengan praktek membuat film dari hasil pengembangan ide para siswa sendiri. Hasil yang diperoleh berupa sebuah film fiksi berdurasi 5 menit. Karya film disajikan dalam kesempatan pameran sekolah bersama karya-karya seni dari minat yang lain. Karya film juga dipersiapkan untuk mengikuti kompetisi film pendek antar sekolah menengah atas atau event kompetisi film lain untuk remaja. Hasil pelatihan menunjukkan bahwa sebagai remaja, siswa SMA memiliki pemahaman dasar tentang teknik pembuatan film sehingga mampu mengaplikasikan teknik-teknik sinematik dalam pembuatan film untuk mendukung penceritaan atau naratif film.
\end{abstract}

Kata kunci: pelatihan, film pendek, siswa SMA. 


\section{Jurnal Batoboh, Vol 3 , No 1 , Maret 2018 \\ FX. Yatno Karyadi}

\section{PENDAHULUAN}

Perkembangan teknologi

komunikasi digital, utamanya internet menjadikan media film mengalami pergeseran dari sisi cara menikmatinya. Kaum remaja usia SMA begitu terimbas oleh penggunaan media berbagi video dan film melalui internet. Dalam kehidupan dan pergaulan sehari-hari, film-film dalam bentuk file video dapat dinikmati melalui gawai yang terhubung dengan jaringan internet. Siswa SMA umumnya memiliki kedekatan dengan media sosial yang berbasis video. Melalui media sosial berbasis video beserta aplikasinya, siswa memiliki kebiasaan memproduksi konten untuk pengisi media sosial mereka. Gaya hidup seperti ini mendukung potensi para siswa yang punya kemampuan berstory telling melalui media audio-visual. Potensi ini perlu didukung dengan kemampuan teknik,estetis, sinematik, dan pengetahuan naratif yang lebih baik.

Metode workshop atau pelatihandirasa sebagai teknik trasnsfer of knowledge yang efektif. Pengetahuan dan ketrampilan tidak perlu diberikan secara mendasar, hanya bersifat pengayaan pengetahuan, karena pada hal $\mid 2$ dasarnya siswa SMA adalah penonton film-film digital dalam kehidupan keseharian mereka melalui gadged seperti personal computer, laptop, tablet dan smartphone. Asumsinya bahwa siswa SMA sudah ter-influence dengan budaya film dalam posisi sebagai penonton, sehingga menjadi lebih mudah bila kemudian berposisi sebagai pembuat film. Pelatihan yang perlu diberikan meliputi prinsip dasar perekaman untuk media film, teknik memperoleh dan mengembangkan ide, teknik pengambilan gambar untuk film, pengetahuan tentang tata suara dan teknik dasar editing film.

Sebagai bagian dari konten audio-visual pada internet, film pendek bagi siswa atau remaja merupakan konten hiburan yang lebih mudah didapatkan melalui perangkat komunikasi elektronik daripada menonton film panjang yang ditayangkan melalui bioskop. Dalam 
hal teknis kebanyakan film pendek menggunakan teknologi yang simpel dan cenderung bersifat instan. Remaja dapat memanfaatkan peralatan pembuatan film rumahan seperti kamera DSLR (digital single lens reflect) atau handycam, dan unit editing berupa komputer atau laptop saja. Dengan modal produksi yang relatif murah siswa sudah dapat mengkomunikasikan ide-idenya melalui media film pendek. Konten yang dibuat untuk film pendek umumnya tentang peristiwa di sekitar sekolah, atau hal-hal yang dekat dengan kehidupan sehari-hari, yang berhubungan dengan gaya hidup dan sifat-sifat dasar pelajar sebagai seorang remaja.

Film adalah media ekspresi yang harus dibuat secara kolektif atau berkelompok. Hal ini mengikat suatu kerjasama antar siswa sebagai kreator untuk senantiasa aktif dalam bekerjasama. Ide dasar cerita film bisa saja bersumber dari satu orang dalam sebuah tim, namun agar menjadi cerita yang menarik dan sempurna biasanya perlu diformulasikan secara bersamasama. Skenario yang mantap pun kelak harus dapat disepahami oleh seluruh anggota tim. Ditambah lagi dengan sistem produksi film yang membagi wilayah kerja menjadi pengarah laku (sutradara), pengarah artistik, pengarah kamera, penata suara, dan penyunting (editor). Agar menghasilkan film yang baik semua dikelola menjadi kerjasama yang saling mendukung capaian film. Terlebih lagi siswa SMA sedang dalam masa-masa pencarian jati diri dan memerlukan kekompakan dalam bekerja.

Film pendek pada prinsipnya adalah sebuah media audio visual melalui gambar bergerak dalam durasi yang singkat. Prinsip dasar dari pembuatan film pendek adalah menyampaikan gagasan atau cerita tertentu, yang utamanya segala penceritaanya digambarkan. Artinya sebuah film dalam durasi singkat pun, lebih baik membuat rangkaian gambargambar daripada berbicara dengan 
suara narasi. Sederhananya, gambargambar yang disajikan harus tetap mampu menceritakan sesuatu atau menginformasikan banyak hal walaupun suara sedang dimatikan. Suara tetap saja penting, namun prinsip film adalah rangkaian gambar-gambar hidup yang bercerita.

Peserta pelatihan adalah siswa SMA Negeri 2 Payakumbuh, Sumatera Barat. Siswa-siswatersebut tergabung dalam ekstrakurikuler gabungan fotografi, film dan jurnalistik. Prioritas anggotanya adalah siswa kelas $\mathrm{X}$ dan kelas XI. Program pelatihan film pendek ini menyasar pengembangan gagasan yang filmis dari peserta usia remaja. Sebagai siswa, film juga merupakan praktek nyata ilmu pengetahuan alam seperti ilmu fisika tentang prinsip optik, cahaya, jarak dan kecepatan. Remaja, dalam usianya yang belia menjadikan film sebagai ajang yang terbuka dalam hal penggalian ide, pengembangan teknik produksi, cara mengekspresikan ide dan teknik dalam menyajikannya kepada penonton.

\section{METODE}

Workshop film pendek dilaksanakan dengan metode praktek memproduksi sebuah film cerita. Tema hal $\mid 4$ film dipersiapkan untuk dapat mengikuti kompetisi film pendek tingkat SMA dalam Festival dan Lomba Seni Siswa Nasional, sedangkan karya film diputar dalam agenda pentas seni seni dan acara perpisahan dengan siswa kelas XII. Praktek dilakukan dengan memberikan materi berupa dasar-dasar pengetahuan tentang film,disertai dengan diskusi tentang penggalian ide-ide, yang kemudian dituangkan dalam bentuk skenario sederhana sebelum dilakukan pengambilan gambar.

Penggalian ide dasar mengenai tema dilakukandengan membuat semacam sketsa mengenai pengalaman-pengalaman siswa di sekolah. Ide dapat merupakan pengalaman pribadi, atau pengalaman orang lain, atau bahkan benar-benar murni khayalan. Siswa dilibatkan dalam diskusi kelompok untuk memilih dan mengembangkan sebuah 
ide yang disepakati dan dipandang paling relevan dengan tema. Untuk memenuhi prinsip alur penuangan ide menjadi film, maka ide dikembangkan menjadi treatment dan selanjutnya ditulis dengan prinsip penulisan skenario yang baku.

Proses produksi dilakukan dengan memberikan prinsip-prinsip tentang penyutradaraan, prinsip tentang shot dasar dalam pengambilan gambar, dasar-dasar tata cahaya, dan prinsip perekaman suara untuk dialog. Prinsip dasar produksi film ini diberikan dan dilakukan secara bersamaan dalam satu pelatihan metode produksi. Artinya sebuah pemilihan tipe shot dan pengaturan kamera serta pengaturan cahaya berpedoman pada amatan di monitor terhadap gambar yang sedang direkam. Demikian juga dengan prinsip perekaman suara yang pengaturannya didasarkan pada pengamatan terhadap suara yang dibutuhkan dalam pengadegan yang berhubungan dengan dialog dan bunyi properti yang terkait langsung dengan cerita film.

Proses editing dilakukan dengan memberikan pemahaman tentang prinsip dasar penyuntingan film. Pelatihan dilakukan secara langsung terhadap materi hasil produksi syuting film. Prinsip dasar yang diberikan berupa penyusunan adegan berdasar potongan shot demi shot, penyusunan adegan demi adegan menjadi babak, serta penyusunan babak demi babak menjadi film utuh. Penyuntingan dilakukan dengan mengutamakan prinsip kontinuitas gambar (continuity editing) seperti prinsip dasar editing film cerita. Dalam penyuntingan juga dilakukan pengaturan suara dialog dan atmosfir yang disesuaikan dengan visual yang ditampilkan. Penambahan efek suara dan ilustrasi musik ditambahkan pada proses paling akhir dari keseluruhan tahapan editing.

Luaran pelatihan adalah terciptanya karya film pendek yang dipertontonkan bagi seluruh siswa dan guru dalam acara pentas dan pameran 
seni sekolah, bersama karya seni rupa dan karya seni pertunjukan lainnya. Karya dipersiapkan pula untuk dikirimkan mengikuti lomba film pendek dalam Festival dan Lomba Seni Siswa Nasional. Karya film ini juga diarsipkan sebagai karya sekolah untuk dapat diikutsertakan dalam kompetisi film pendek independen dan sebagai arsip prestasi sekolah.

\section{PEMBAHASAN}

Sebagai sebuah kegiatan ekstra kurikuler, pembuatan film pendek adalahsebuah proses yang mengasyikkan. Peran aktif para siswa dalam keseluruhan proses produksi mengindikasikan antusiasme yang tinggi pada seni film. Pelatihan dan pendampingan bidang seni merupakan ajang kreativitas, penyaluran hobi dan bakat siswa. Pada dasarnya siswa sebagai remaja adalah pembuat adegan atau perekam hal-hal menarik dalam aktivitas keseharian mereka melalui perangkat smartphone, kamera action, atau kamera DSLR.
Bermodalkan visual habit ini kebanyakan remaja memilih media yang terintegrasi dengan internet. Akibatnya, para siswa mampu hal $\mid 6$ mereferensi film-film melalui jejaring sosial media yang berbasis audio visual seperti YouTube, Instagram atau aplikasi menonton film seperti Viu misalnya.Hal ini tentu berguna dalam praktek pembuatan film dan metode visualisasi ide dasar pembuatan film. Pelatihan pembuatan film bagi siswa SMA cukup memberi tambahan masukan dari sisi estetikanya. Dalam hal ini dilakukan eksperimen-eksperimen tentang teknik visualisasi gagasan agar terintegrasi dengan jalannya cerita.

$$
\text { Spesifikasi teknis yang }
$$

dikehendaki dalam pelatihan film pendek ini adalah film digital dengan kualitas HD (high definition), sebuah standar teknis yang umum untuk dapat diterima pada berbagai media, pada berbagai aplikasi audio-visual dan pada berbagai kompetisi. Karenanya sebagai pengantar diberikan dasardasar mengenai videografi dengan kamera DSLR beserta pengaturan 
kualitas video yang dihasilkan. Dalam praktek diberikan juga teknik komposisi obyek, tipe-tipe shot, dan teknik tata cahaya. Pada aspek estetika diberikan pengetahuan mengenai kontiniti arah pandang dan kontiniti gerak, garis axis, dan model perekaman gambar master scene.

Pengetahuan dasar tentang videografi dapat tercapai dan dipahami secara baik. Dalam kesempatan praktek,siswa mampu mengaplikasikan dan mengintegrasikan mata pelajaran ilmu pengetahuan alam utamanya ilmu fisika.Prinsip dasar ilmu fisika untuk pembuatan film meliputi optik, cahaya, waktu, jarak dan kecepatan. Prinsipprinsip estetika diperoleh dari eksperimen tentang komposisi obyek, pengaturan dan pemilihan warna obyek serta pemilihan dan pengaturan peran, aksi dan ekspresi pemain. Sedangkan dari keilmuan sosial produksi film membangkitkan selera seni, kepemimimpinan, manajemen dan teknik komunikasi antar siswa.
Pelatihan film pendek untuk siswa di SMA 2 Payakumbuh terlaksana melalui pertemuan reguler setiap hari Sabtu selama bulan April 2018. Pelatihan ini menghasilkan sebuah karya film pendek berdurasi 5 menit dengan tema "keteladanan berkarakter". Ide dasarnya mencerminkan gaya hidup remaja milenial masa kini. Ide pokok dalam film ini diperoleh dan dikembangkan oleh peserta pelatihan pada setiap pertemuan. Karya film dirancang dalam durasi pendek, namun harus mampu menyajikan seluruh gagasan utama film. Karya film menggambarkan ekspresi diri para siswa melalui peristiwa yang terjadi dalam kehidupan di sekolah yang dialami oleh para pembuatnya. Ide pokok dituangkan dalam sebuah skenario berjudul "Individualisme" (Adi dan Rani).

\section{Skenario}

Sebuah gagasan untuk film cerita, umumnya dituangkan ke dalam sebuah skenario. Skenario akan 
memberikan gambaran yang dapat (Mabruri, 2009, p.17). Langkah dipedomani oleh seluruh anggota yang pembuatan skenario terdiri dari terlibat dalam pembuatan sebuah film. penentuan ide pokok cerita dari sebuah Skenario dijadikan pijakan untuk tema, membuat cerita dasar (basic hal|8 membuat gambar-gambar saat story), membuat sinopsis, membuat dilakukan syuting. Skenario yang treatment dan membuat skenario. lengkap akan memuat urutan nomor adegan, setting tempat dan waktu kejadian dalam adegan. Isinya terdiri atas keterangan adegan, bisnis atau aksi yang harus dilakukan, properti yang berkait dengan aksi, nama peran serta dialog para peran. Panjang pendeknya skenario akan menentukan panjang pendeknya durasi film pula. Durasi sebuah film dapat diperkirakan dari banyaknya adegan yang termuat dalam skenario.

Skenario film memiliki suatu tema yang dikembangkan dari sebuah ide. Ide cerita film bersumber dari diri sendiri dan lingkungan di sekitarnya, cerita rakyat, inspirasi, khayalan, bacaan, hobi, sejarah dan sebagainya. Sebuah cerita fiksi tidak perlu dibuat persis seperti kenyataan, tetapi boleh memasukkan unsur khayalan kreatif agar cerita menjadi lebih menarik

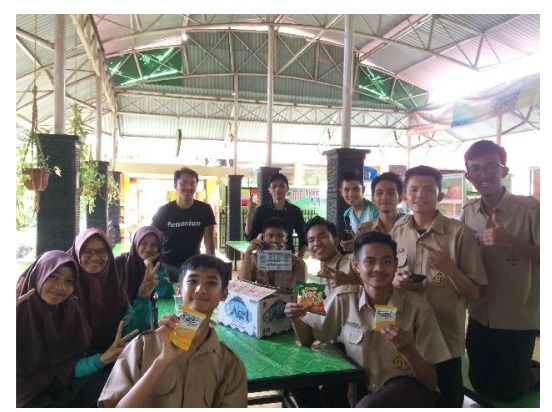

Gambar 1

Proses penggalian dan pengembangan ide cerita.

(Foto: Doni F, 2018)

Ide dasar cerita diperoleh dari seorang siswa yang dalam sebuah diskusi kemudian disepakati dan dikembangkan bersama. Pokok cerita adalah tentang Adi, seorang siswa yang sangat ketergantungan dengan gadget. Adi menjadi asyik sendiri dengan dunianya sehingga mengabaikan interaksi dengan kawan-kawan sekelasnya. Adalah Sari, seorang siswa lain yang menaruh perhatian dan selalu mengamati gerak-gerik Adi. Pada suatu ketika Adi kehilangan smartphone 
kesayangannya. Tingkah Adi menjadi aneh. Adi juga merasa jauh dari temantemannya. Secara kebetulan Sari lah yang menemukan kembali gadget Adi. Mengetahui tingkah aneh Adi, sembari mengembalikan smartphone itu Sari memberikan sebuah nasehat untuk Adi.

\section{Syuting}

Proses produksi film yang sebenarnya adalah proses pengambilan gambar atau syuting. Pada tahap ini seluruh unsur film dibuat dan diatur sedemikian rupa. Pengaturan meliputi tata kamera, yaitu mengatur cara-cara perkaman gambar film sesuai dengan teknologi yang relevan. Tata artistik adalah pengaturan terhadap set/setting yang mengacu pada logika tempat terjadinya peristiwa pada film, dan waktu dalam hari seperti siang/malam dan waktu masa yaitu: masa kini, masa lalu atau masa depan. Dalam tata artistik termasuk di dalamnya kostum dan make-up. Tata cahaya adalah pendukung terciptanya gambar melalui kamera yang selain menerangi juga mengindikasikan waktu dalam hari seperti siang atau malam, juga untuk menimbulkan kesan dimensi pada gambar. Tata suara adalah pengaturan terhadap perekaman suara untuk film seperti dialog pemain, ambien dan efek suara.

Terdapat lima acuan dasar untuk pengambilan gambar pada saat syuting. Kelima dasar itu adalah camera angle, continuity, cutting, close-up dan composition (Marcelli, 2010). Camera angle adalah sudut pandang kamera pada saat memvisualkan obyek. Di dalamnya juga memuat ukuran gambar yang terdiri atas yaitu sudut pengambilan extreme long shot(sangat jauh), longshot (jauh), medium shot (sedang), medium close-up (lebih dekat), close up (dekat) dan extreme close-up (sangat besar). Continuity atau kontinitas adalah kebersambungan ruang dan waktu dalam film. Close-up adalah menyiapkan gambar ukuran besar yang memberi detail informasi. Cutting adalah menyiapkan pilihanpilihan tipe shot yang mungkin diolah 


\section{Jurnal Batoboh, Vol 3 , No 1 , Maret 2018 \\ FX. Yatno Karyadi}

kembali pada proses editing. mikropon berjenis shotgunmic sebagai Composition adalah penempatan perekam suara.

kesatuan dan keserasian obyek pada saat syuting.

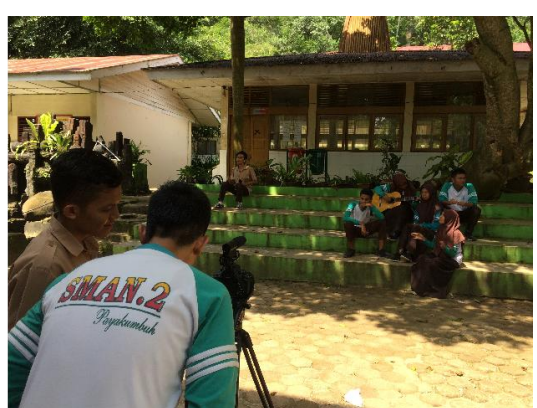

Gambar 2

Pengambilan gambar (syuting).

(Foto: Doni F, 2018)

Pada pelatihan film pendek ini proses pengambilan gambar berlangsung pada siang hari dan memanfaatkan cahaya alami. Jumlah adegan yang dipersiapkan dalam skenario terdiri dari 15 scene. Masingmasing scene diperkirakan divisualisasikan dalam durasi 20-30 detik. Terdapat beberapa scene yang menggunakan dialog, dan beberap scene yang lain berdurasi lebih panjang karena kompleksitas rancangan shot yang telah dibuat sebelumnya. Peralatan syuting yang digunakan adalah kamera DSLR, pencahayaan tambahan dengan lampu $L E D$, dan

\section{Editing} hal | 10

Editing adalah proses menyusun potongan-potongan gambar yang diperoleh dari rekaman pada saat syuting.Gunanya adalah untuk membuat urutan shot demi shot menjadi scene/adegan, adegan demi adegan menjadi babak/sequence dan babak demi babak menjadi film yang utuh. Hal ini diperlukan karena biasanya pada saat syuting, gambar direkam secara acak berdasarkan lokasi tertentu atau urutan waktu syuting dan set siang atau malam. Selain itu editing berguna untuk merapikan dan membuang bagian yang tidak diperlukan. Selain menata gambar, proses editing juga menata suara seperti dialog pemeran yang terlalu keras atau terlalu lemah. Dalam hal editing suara, juga dimasukkan unsur musik ilustrasi dan efek suara khusus yang berfungsi meningkatkan dramatisasi film. 
Editing film menggunakan sistemnon-linier editing (NLE). Prinsip operasional non-linier editingadalah memilih file data video dan audio dalam komputer dan memutar ulang dalam urutan tertentu. Editing nonlinier dilakukan dengan memilih dan mengurutkan gambar yang telah ditransfer dari kamera video ke hard drive komputer dari sistem editing. Ketika menggunakan software editing untuk mentransfer sumber rekaman kamera ke hard drive komputer, maka kita sudah melakukan praktek editing non linier (Zettl, 2009, p.422).Software editing adalah perangkat aplikasi komputer khusus untuk penyuntingan film digital.

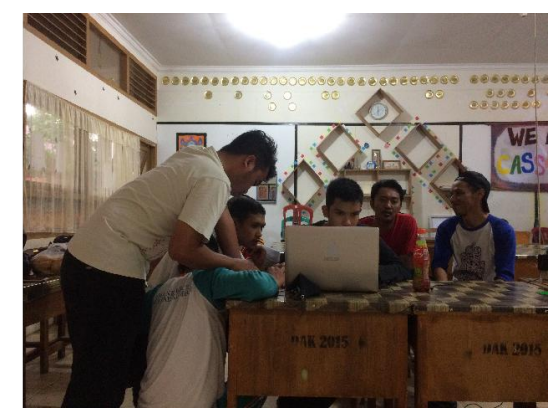

Gambar 3

Penyuntingan film (proses editing).

(Foto: Doni F, 2018)

Aplikasi editing yang digunakan untuk penyuntingan film pendek ini adalah Adobe Premiere, software yang sangat populer dalam dunia produksi film. Software ini tergolong mudah dipelajari termasuk oleh siswa SMA sekalipun. Materi yang dihasilkan dari proses syuting sebelumnya tergolong cukup ringan, mengingat durasi yang dirancang cukup pendek. Gambar, suara, transisi, efek suara yang dikerjakan memiliki stok yang cukup untuk membuat jalinan cerita yang utuh. Ilustrasi musik yang digunakan diperoleh dari penyedia konten musik tanpa hak cipta, yang diperoleh dengan mengunduh melalui situs penyedia konten tak berbayar. Setelah proses editing selesai dihasilkan sebuah film pendek berdurasi 5 menit.

\section{Film Pendek "Individualisme" (Adi dan Rani )}

Film pendek memiliki ciri dari sisi durasi yang singkat, bersifat non komersial, tidak mengenal star, dan aturan produksinya sederhana (Prakosa, 1997, p.2). Sebelumnya film pendek dikenal dengan istilah film 


\section{Jurnal Batoboh, Vol 3 , No 1 , Maret 2018 \\ FX. Yatno Karyadi}

mini. Fungsinya adalah untuk tentang proses penyadaran sikap tokoh menyampaikan gagasan tertentu tanpa antagonis untuk bersikap wajar atau memaparkan secara detail latar meneladani tokoh protagonis yang belakang cerita dan asal usul para lakon film. Kekuatannya adalah pada visual yang disusun dan dibuat di depan kamera. Informasi sepenuhnya berupa informasi visual. Dalam hal ini peran suara seharusnya sebagai unsur penguat saja. Hasil karya para siswa tersebut mengambil latar di sekolah. Informasi tentang tokoh Adi dan Rani cukup digambarkan dengan kostum berupa seragam sekolah. Demikian juga dengan konflik digambarkan melalui tingkah laku dan gerak-gerik tokoh.

Untuk mengapresiasi sebuah film umumnya dijembatani oleh pertanyaan mengenai apa tema yang disampaikan, bagaimana alur ceritanya, bagaimana penokohan/karakterisasinya, apa konflik penggerak ceritanya, dan kewajaran aksi para pemainnya (Sumarno, 1996, p.50). Tema film adalah tentang keteladanan berkarakter. Alur ceritanya adalah dipandang lebih ideal dalam bergaul. hal $\mid 12$ Pengkarakteran dibangun dengan menampilkan sebab-akibat atas perbuatan tokoh antagonis. Konflik diperoleh dengan karakter antagonis yang selalu asyik dengan dunia gadget sehingga mengabaikan interaksi dengan lingkungan sekitarnya (aksi phubbing). Sedangkan para pemeranan karakter utamanya cukup baik mengingat aksinya memiliki kedekatan dengan lingkungan sekolah sebagai siswa.

Unsur pembentuk fiksi filmbiasanya memuat simbolisme, karakterisasi, konflik, setting, pemberian judul film, ironi, kualitas sinematik, editing, efek visual, tata cahaya, warna, efek suara, musik, akting dan gaya penyutradaraan (Boggs, 1992, pp. 308-325). Simbolisasi dari dari aksi phubbing difilmkan dengan cara memilih pola perbandingan, misalnya: diskusi kelompok vs chatting sosial media, 
bermain basket vs bermain game di smartphone, bernyanyi bersama vs mendengarkan musik melalui earphonedan sebagainya. Secara umum kualitas sinematik, editing, pencahayaan, musik dan akting cukup baik untuk mendukung cerita film. Sementara untuk gaya penyutradaraan, bagi pembuat film pemula belum dapat dinilai memiliki gaya penyutradaraan tertentu.

Terdapat dua unsur pembentuk film yakni usur naratif dan unsur sinematik. Unsur naratif adalah cerita serta perlakuan pembuat film terhadap cerita pada film. Unsur-unsur sinematik terdiri dari: mise-en-scene, sinematografi, editing dan suara (Pratista, 2008). Secara naratif gagasan pokok dapat disajikan dalam durasi yang singkat melalui pilihan-pilihan pengadeganannya. Unsur sinematik yang dibangun melalui mise-en-scene meliputi: setting di sekolah, kostum berupa seragam harian, tata cahaya untuk siang hari yang memanfaatkan available light, dan akting siswa yang memerankan sosok pelajar cukup meyakinkan. Editing dan suara cukup rapi dan mendukung jalannya penceritaan film.

Dalam tataran yang lebih luas film berfungsi sebagai media penerangan kepada masyarakat atau kelompok masyarakat, dan memiliki fungsi edukasi atau mendidik (Siagian, 2006, p.8). Film karya para siswa ini memberikan informasi kepada masyarakat bahwa fenomena phubbing semisal: tidak merespon lawan bicara karena asyik bermain smartphone, atau tidak bertegur sapa karena fokus pada gadget, tidak fokus mengerjakan sesuatu sambil sesekali melirik notifikasi, dan menyela diskusi atau obrolan untuk membalas chat adalah fenomena yang nyata. Film ini, membidik kelompok masyarakat pelajar untuk sadar akan komunikasi nyata dan mendidik masyarakat luas untuk dapat bermedia secara bijak, dan agar menyadari bahwa berinteraksi secara langsung adalah penting. 


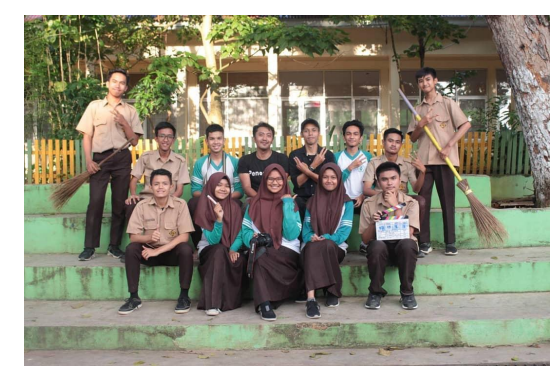

\section{Gambar 4}

Peserta workshop film pendek SMA 2 Payakumbuh.

(Foto: Doni F, 2018)

\section{SIMPULAN}

\section{Kesimpulan}

1. Film pendek hasil produksi siswa SMA menunjukkan bahwa pada siswa memiliki ketertarikan pada media film. Film dapat dijadikan ajang ekspresi diri dan ruang untuk mengungkapkan gagasan tentang fenomena di lingkungan sekitar. Siswa mampu mempertontonkan karya film sebagai media ekspresi diri.

2. Teknik produksi film digital (digital cinema) merupakan teknik pembuatan film yang sangat memudahkan setiap proses kreatif pembuat film, termasuk pembuat film pemula. Berbekal pengetahuan ilmu fisika, para siswa mampu hal $\mid 14$ mengaplikasikan pemilihan shot, angle dan komposisiuntuk merangkai gambar yang mampu mendukung tema cerita film.

3. Tema dan ide dasar dalam pembuatan film pendek di kalangan siswa SMA rataratamerujuk pada pengalaman terhadap lingkungan sekitar, dan terdorong pula oleh berbagai referensi yang umumnya diperoleh melalui media sosial.

\section{Saran}

1. Perlu pembekalan dasar-dasar pembuatan film serta prinsip dasar videografi untuk memudahkan visualisasi karya film pendek yang bernilai estetis baik secara visual, secara naratif dan konten cerita yang menarik,serta dekat dengan kehidupan remaja. 
2. Guna memperkaya portofolio para siswa dan untuk memacu kreativitas, siswa dapat berlatih menggunakan peralatan teknis yang lebih simpel seperti smartphone untuk memfilmkan berbagai peristiwa di lingkungan sekitar dalam rangka membiasakan diri membuat dan menyusun informasi visual.

\section{KEPUSTAKAAN}

Boggs, Joseph M. (1992), Cara Menilai Sebuah Film. Terjemahan oleh Asrul Sani. Jakarta: Yayasan Citra.

Mabruri, Anton. (2009), Penulisan Naskah TV, Depok: Mind 8 Publishing.

Marcelli, Joseph V. (2010), Lima Jurus Sinematografi. Terjemahan oleh Misbah Yusa Biran. Jakarta: FFTVIKJ.

Prakosa, Gotot. (1997), Film Pinggiran: Ontologo Film Pendek, Film Eksperimental dan dan Film Dokumenter, Jakarta: FFTV-IKJ.

Pratista, Himawan. (2008), Memahami Film, Yogyakarta: Homerian Pustaka.

Siagian, Gayus. (2006), Menilai Film, Jakarta: Dewan Kesenian Jakarta.
Sumarno, Marselli. (1996), Dasar-dasar Apresiasi Film, Jakarta: Gramedia Widia Sarana.

Zettl, Herbert. (2009), Television Production Handbook, Belmont: Wadsworth Cengage Learning.

i

